\title{
IDIOPATHIC HYPOPROTEINAEMIC OEDEMA AND AMINO-ACIDURIA IN AN INFANT
}

\author{
BY \\ J. P. BOUND and W. R. HACKETT \\ From the Departments of Paediatrics and Biochemistry, Hillingdon Hospital, Middlesex
}

(RECEIVED FOR PUBLICATION OCTOBER 27. 1952)

\begin{abstract}
Hypoproteinaemic oedema may result from a deficiency of protein in the diet or interference with its absorption from impaired synthesis of serum proteins in the liver, or from loss of protein, as in albuminuria. In some cases, termed idiopathic hypoproteinaemia, the cause is obscure. A few examples in children are on record. Schick and Greenbaum (1945) described an 11-year-old girl who had had recurrent oedema from birth: the serum albumin and globulin, and especially $\gamma$ globulin, were decreased. In the case of a boy reported by Hertzog and Faust (1950) the serum proteins had returned to normal when he was 5 months old.
\end{abstract}

Homburger and Petermann (1949) described a syndrome of idiopathic familial dysproteinaemia characterized by abnormalities in the electrophoretic patterns of the plasma with or without hypoproteinaemia. These were accompanied in the adult by peripheral vascular changes and oedema. In no case was the albumin lowered to the extent usually required to produce oedema, and a constitutional inferiority of the vascular system was postulated. Although oedema did not appear until after puberty, it is of interest that the mother of certain of the cases had five oedematous, stillborn foetuses although she was $R h$ positive.

Disorders of amino-acid metabolism have been reviewed by Dent (1951). Apart from easily distinguished abnormalities in which a specific aminoacid is excreted in the urine (e.g. phenylpyruvic oligophrenia), there is a group of conditions in which cystine, with or without various other amino-acids, is found in increased amounts in the urine. This group Dent divided into (1) renal cystinuria, where there is a normal concentration of cystine in the plasma and amino-aciduria results from a lowered renal threshold, and (2) hepatic cystinuria, in which amino-aciduria is a reflection of a raised plasma concentration of cystine and other amino-acids. Renal cystinuria includes the de Toni-Debré-Fanconi syndrome, Wilson's disease and the condition long known as cystinuria, in which renal calculi made of cystine may be formed. Hepatic cystinuria occurs in mild and chronic disorders of the liver, as well as in more severe affections such as acute yellow atrophy.

More recently, Holzel, Komrower and Wilson (1952) have reported the occurrence of aminoaciduria in two cases of galactosaemia. In this condition hepatic damage may occur, and Mellinkoff, Roth and MacLaggan (1945) reported the case of a boy who developed oedema, associated with lowering of the plasma proteins and hepatomegaly, at the age of 6 weeks.

It will be seen that, among the causes of hypoproteinaemic oedema and amino-aciduria respectively, hepatic disease and galactosaemia are common to both. Although hepatomegaly may be a feature of the de Toni-Debré-Fanconi syndrome, alteration of the serum proteins is not found (Debré, 1947). In the family with idiopathic dysproteinaemia described by Homburger and Petermann (1949) the amino-acids of the plasma and urine were studied by chromatography and no abnormalities found. Thus, in an infant showing both hypoproteinaemic oedema and amino-aciduria, other evidence of liver disease or of galactosaemia might be expected. In the case to be presented no such evidence was found.

\section{Case Report}

D.B., a boy aged 1 month, was admitted to Hillingdon Hospital on September 13, 1950. He was the fourth child, and had been born at home by a forceps delivery, the birth weight being $10 \mathrm{lb}$. Swelling of the feet was noticed at birth, and four days before admission the legs had also become swollen. He had been entirely breast fed, but the mother thought that she had insufficient milk, and he had gained only $4 \mathrm{oz}$. over his birth weight. There had been no diarrhoea or vomiting.

The first sibling. a girl, had swelling of the feet from birth, and had pitting oedema of the feet and legs when 


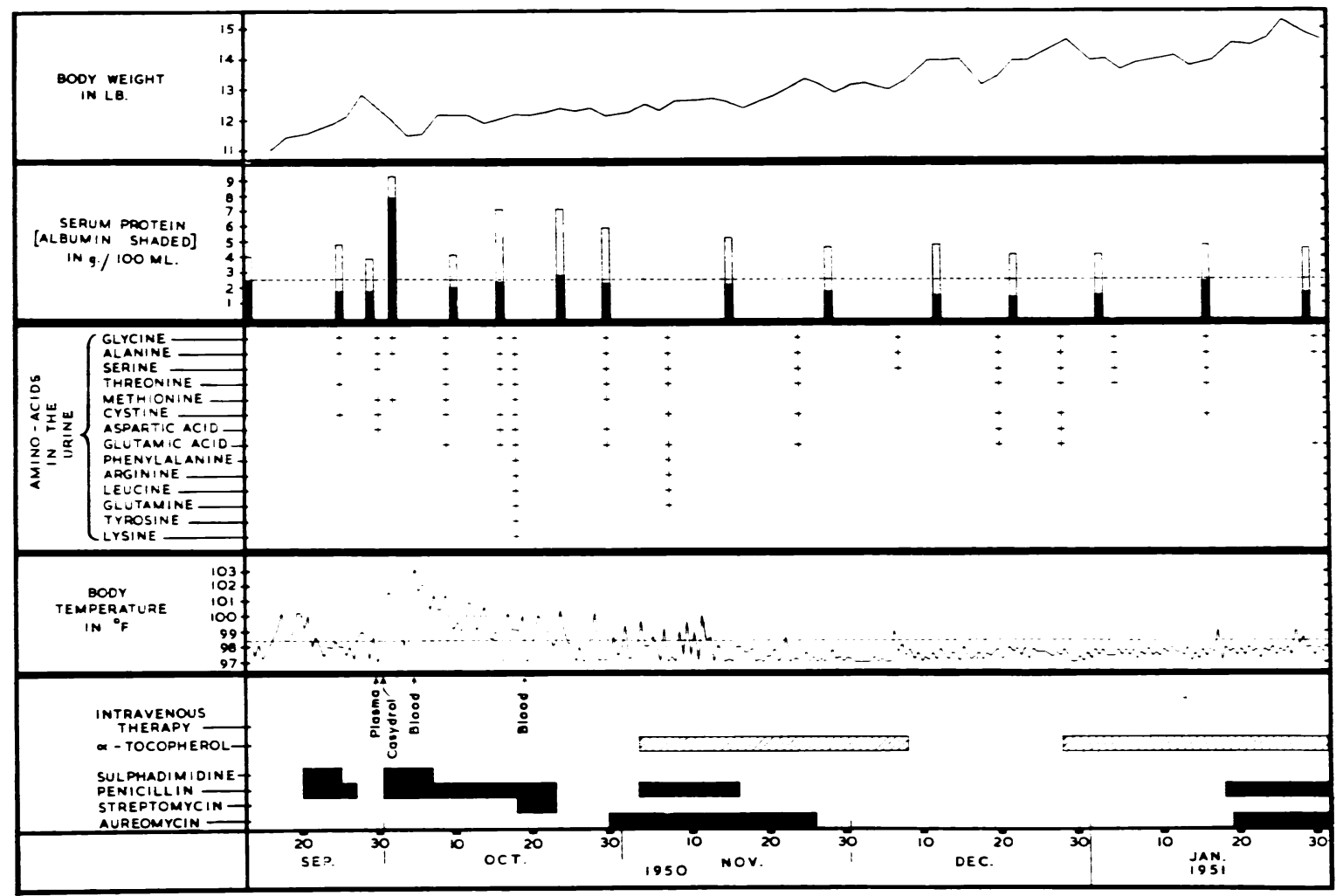

FKG. 1.-Chart of progress and treatment during the first four-and-a-half months.

seen at another hospital at the age of 7 weeks. Subsequently oedema of the trunk and arms was noted, and ascites gradually developed, paracentesis being performed on several occasions. She died at the age of 6 months, and during the previous week two estimations of the total serum proteins gave values of 3.05 and $3.4 \mathrm{~g} .100 \mathrm{ml}$. respectively. At necropsy, in addition to the oedema and ascites, osteomyelitis of the fourth and fifth right ribs and the manubrium sterni, a purulent pericarditis and multiple staphylococcal abscesses of the lungs and kidneys were demonstrated. The liver was macroscopically normal, but frozen sections showed extensive fatty infiltration, with a degree of portal cellular reaction. There was no obstruction of the superior or inferior vena cava or of the thoracic duct.

Two other children, a girl aged 3 years and a boy aged 1 year and 10 months, were alive and well. The parents were not related. The two healthy children and the parents had normal serum proteins as demonstrated by electrophoresis and chemical analysis, and no increased urinary excretion of amino-acids.

On examination marked pitting oedema of the feet and legs, and a lesser degree of oedema of the thighs, sacrum, hands and forearms was seen. There was no clinical anaemia. The heart was not enlarged, and no murmurs were audible. The baby had a nasal discharge but the lungs were clear, apart from rhonchi at the right base. The abdomen was slightly protuberant and showed a small umbilical hernia: the liver and spleen were not palpable. There was no neck rigidity.

The main features of the boy's progress during the first four and a half months are shown in Fig. 1.

Laboratory Investigations. During the first two weeks after admission the following investigations were carried out.

The urine showed no albumin or reducing substance, and the centrifuged deposit yielded a few leucocytes only.

A radiograph of the chest revealed no pulmonary lesion, and the cardiac contours were normal.

A blood count gave haemoglobin $13 \mathrm{~g}$. per $100 \mathrm{ml}$.; red cells $3 \cdot 84$ million per c.mm.: leucocytes 11,500 per c.mm. $\left(53^{\circ}\right.$ o neutrophils, $40^{\circ}$ o lymphocytes and $7^{\circ}$ o monocytes). The sedimentation rate was $17 \mathrm{~mm}$. in one hour (Westergren).

The total serum protein was $4 \cdot 0 \mathrm{~g}$. per $100 \mathrm{ml}$. (albumin $2 \cdot 5 \mathrm{~g}$. per $100 \mathrm{ml}$., globulin $1 \cdot 5 \mathrm{~g}$. per $100 \mathrm{ml}$.). (Globulin precipitation was carried out by the method of Cohn and Wolfson, 1948.)

The serum bilirubin level was less than $0.2 \mathrm{mg}$. per $100 \mathrm{ml}$. The alkaline phosphatase was $14 \mathrm{King}$-Armstrong 
units per $100 \mathrm{ml}$. Thymol turbidity was 0 units. Kunkel's specific gamma globulin test (zinc sulphate turbidity) gave 0 units. The serum inorganic phosphorus level was $6 \cdot 3$ mg. per $100 \mathrm{ml}$.; serum chloride level $632 \mathrm{mg}$. per $100 \mathrm{ml}$. (as sodium chloride); blood cholesterol level $130 \mathrm{mg}$. per $100 \mathrm{ml}$.; blood urea $30 \mathrm{mg}$. per $100 \mathrm{ml}$.; blood galactose $0 \mathrm{mg}$. per $100 \mathrm{ml}$. The blood Wassermann reaction was negative.

Urine chromatography showed heavier bands of glycine and alanine than in the urine of a normal baby, and in addition, threonine and a trace of cystine were present (Fig. 2a). For all chromatographs 25 microlitres of an early morning specimen of urine were used, and run in phenol-water. having fallen to $8 \mathrm{~g}$. per $100 \mathrm{ml}$. and the red cells to 2.5 million per c.mm., a transfusion of $120 \mathrm{ml}$. of packed red cells was given.

Eleven days later two abscesses were noted along the line of the cephalic vein above the site of the previously septic wound. Pus was aspirated, and culture produced zoliform organisms and coagulase-positive penicillinresistant staphylococci. A five-day course of streptomycin was given in addition to the penicillin but this did not influence the pyrexia, and both drugs were stopped. At this time a further transfusion of $200 \mathrm{ml}$. of blood was given for anaemia (haemoglobin $8.6 \mathrm{~g}$. per $100 \mathrm{ml}$.).

On October 29 purulent arthritis of the right knee developed, and led to the discovery of an area of osteomye-

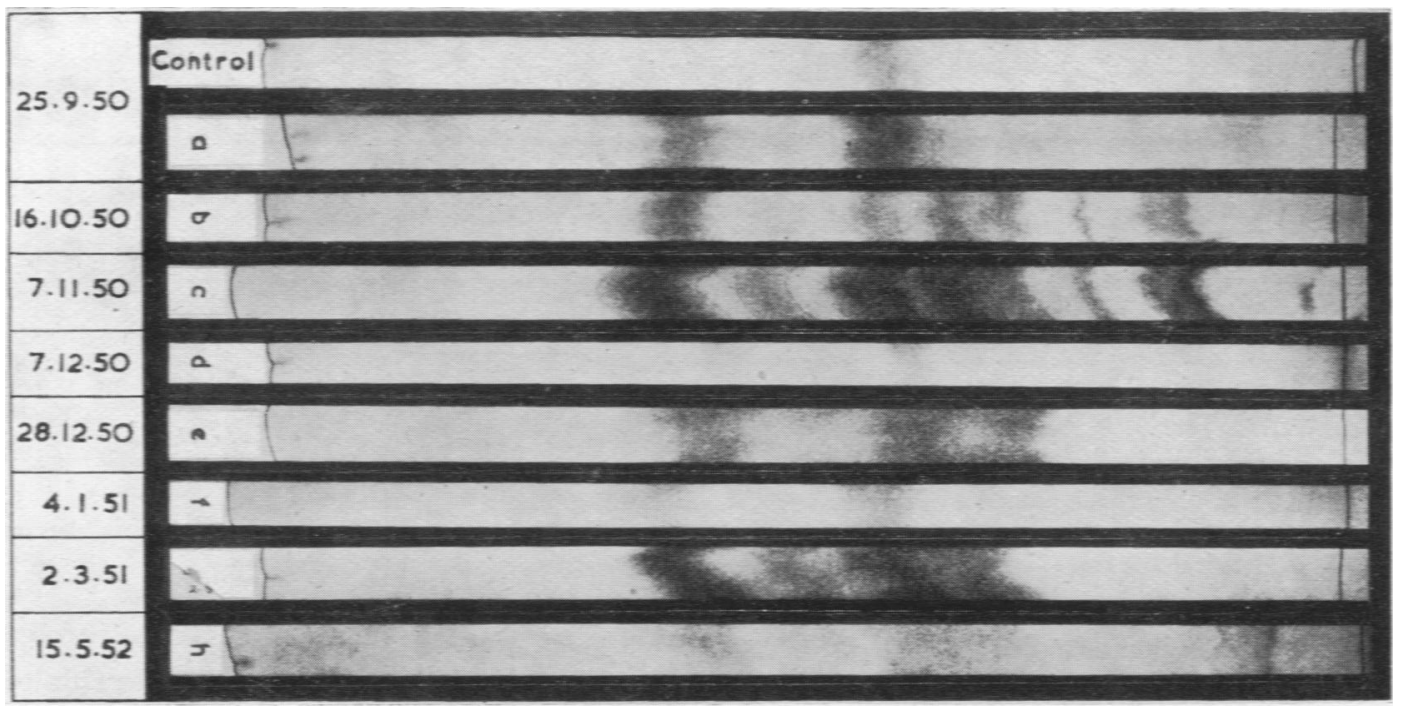

Fig. 2.-One-dimensional chromatograms.

During this period the oedema increased with the development of gross swelling of the lower legs and scrotum, ascites and puffiness of the eyelids. On September 17 pyrexia developed, for which no cause was found. A course of penicillin and sulphadimidine was begun on the fourth day, and the pyrexia rapidly subsided. The infant was fed on half cream National dried milk, and received daily supplements of vitamins $A, D$ and $C$. Vitamin B complex was given intramuscularly daily for five days, and thereafter weekly.

Period of Increasing Amino-Aciduria. On September 291 pint of plasma was given intravenously, and resulted in a profuse diuresis and marked diminution in the oedema. The plasma was followed by injection of intravenous 'casydrol', which caused some increase in the amino-aciduria. Two days after the administration of plasma pyrexia appeared again, and the intravenous drip wound was noted to be inflamed. Penicillin was administered, together with sulphadimidine for the first six days, but some fever persisted. On October 4, the haemoglobin litis in the upper part of the right femur and a small focus in the left tibia. Aureomycin therapy was begun, and subsequently penicillin was restarted in a larger dose than previously.

Throughout this five-week period a variable degree of oedema of the feet and legs persisted. A striking feature was the increasing amino-aciduria shown by the onedimensional chromatograms (Fig. 2b). On October 19. when seven bands were identified as on October 17, a twodimensional chromatogram revealed 15 amino-acids and one unidentified substance. These findings were confirmed for us by Dr. C. E. Dent of University College Hospital (Fig. 3). At this time the serum amino nitrogen level, estimated by the method of Albanese and Irby (1945). was $8.6 \mathrm{mg}$. per $100 \mathrm{ml}$.

Period of Therapy with Vitamin E. On November 3 oral administration of $x$-tocopherol, $150 \mathrm{mg}$. daily, was begun. Six days later swelling of the right shoulder was found to be due to osteomyelitis of the upper end of the humerus. On November 15 a radiograph of the femora 
showed that there was osteomyelitis of the upper end of the bone on the left side, as well as on the right. By November 26 the temperature had been normal for two weeks, the swellings caused by the osteomyelitis were subsiding, and the sedimentation rate was only $9 \mathrm{~mm}$. in the first hour: aureomycin was withdrawn, and no evidence of a relapse followed. Amino-aciduria had reached its maximum on November 7 (Fig. 2c) and thereafter decreased, being almost normal on December 7 (Fig. 2d). There was some increase in the oedema of the feet and legs.

On December 8 therapy with $x$-tocopherol was stopped for three weeks. During this period the infant's feeds were gradually changed to full cream National dried milk, and on December 16 'casilan' was added to them. The amino-aciduria increased again, and on December 28 approached the previous maximum (Fig. 2e). The increased oedema persisted. There was no clinical evidence of any active infection, and radiographs (December 20) showed very marked reconsolidation of the areas of osteomyelitis.

On December 28 a second course of therapy with $x$-tocopherol was begun, and continued for 30 weeks. After one week the amino-aciduria again showed a marked reduction (Fig. 2f) and oedema decreased. On January 15, 1951, a recurrence of the osteomyelitis of the left tibia, with subperiosteal abscess formation but little pyrexial response, was associated with a mild, temporary increase in amino-aciduria, the serum amino nitrogen level being $6.4 \mathrm{mg}$. per $100 \mathrm{ml}$. The infection subsided with a further course of aureomycin and penicillin. On February 24 the infant developed bronchitis with initial diarrhoea. There was a considerable increase in aminoaciduria (Fig. 2g), with a serum amino nitrogen level of $9.1 \mathrm{mg}$. per $100 \mathrm{ml}$. When this infection was controlled amino-acid excretion soon diminished and was subsequently either normal or slightly increased. The serum amino nitrogen level was then $5.3 \mathrm{mg}$. per $100 \mathrm{ml}$. Oedema increased temporarily with each infection, but thereafter was minimal.

During the first four and a half months of this second course of $\boldsymbol{x}$-tocopherol, the total serum protein concentration lay between 3.35 and $5.35 \mathrm{~g}$. per $100 \mathrm{ml}$. and the albumin between 1.35 and $2.4 \mathrm{~g}$. per $100 \mathrm{ml}$. with an albumin-globulin ratio of $0 \cdot 5$ to $1 \cdot 2$. On May 111 pint of plasma was given intravenously and produced a diuresis. The total serum protein concentration was not altered, but the serum albumin persisted above $2 \mathrm{~g}$. per $100 \mathrm{ml}$. and the albumin-globulin ratio was normal for three weeks. Subsequently, the serum albumin concentration was again less than $2 \mathrm{~g}$. per $100 \mathrm{ml}$. on occasions, with an albumin-globulin ratio down to $0 \cdot 6$. Fractionation of the serum proteins according to the method of Martin, Morris and Smith (1950) on May 31 showed albumin $2.76 \mathrm{~g}$. per $100 \mathrm{ml}$., $x$ globulin $0 \cdot 87, \beta$ globulin 0.37 and $\gamma$ globulin $0.10 \mathrm{~g}$. per $100 \mathrm{ml}$.

At the end of February, when the infant was 6 months old, cereal was added to his feeds, and over the next three months a weaner's diet was gradually introduced, still with the addition of 'casilan'. On June 4 he was discharged home, and kept under observation in the Outpatient Department. $x$-Tocopherol was stopped on July 23.

Follow-up Period. Over the next 10 months he remained well, apart from a persistent nasal discharge at first. Minimal oedema of the feet was sometimes present, but often there was none. Amino-acid excretion in the urine was normal or slightly raised. On December 21 , 1951, liver function tests showed the serum bilirubin to be less than $0.2 \mathrm{mg}$. per $100 \mathrm{ml}$., the alkaline phosphatase 17 King-Armstrong units per $100 \mathrm{ml}$., thymol turbidity 1 unit and total serum proteins 5.7 g. per $100 \mathrm{ml}$. (albumin $2 \cdot 3, \alpha$ globulin $3 \cdot 0, \beta$ globulin $0 \cdot 4$ and $\gamma$ globulin 0 g. per $100 \mathrm{ml}$.). 
On May 15, 1952 (at the age of 21 months), his general development was satisfactory, except that he had not walked until the age of 19 months, and had a waddling gait. A radiograph revealed subluxation of the right hip. There was minimal oedema of the feet. The total serum protein was $3.55 \mathrm{~g}$. per $100 \mathrm{ml}$. (albumin 2.05 and globulin $1.50 \mathrm{~g}$. per $100 \mathrm{ml}$.). Serum electrophoresis showed that most of the globulin was $\beta$ globulin with rather less $x 2$ globulin: there was a trace of $x 1$ globulin and $\gamma$ globulin was absent (Fig. 4). The serum amino nitrogen level was $6.6 \mathrm{mg}$. per $100 \mathrm{ml}$. Urine chromatography showed normal amounts of glycine and alanine, with a trace of cystine, aspartic acid, serine and threonine (Fig. 2h). The Schick test was negative. and galactosuria was absent. Further, when aminoaciduria was marked the pattern of the twodimensional chromatogram, with cystine and lysine predominating, was unlike that of hepatic disease, although the W-spot had previously been seen only in such cases (Dent, 1950). Finally, hypoproteinaemia in hepatic disease is almost entirely due to a lowered concentration of serum albumin, whereas an additional feature in our case was the virtual absence of $\gamma$ globulin.

At this point it must be remembered that the first sibling had also shown oedema from birth, and had a

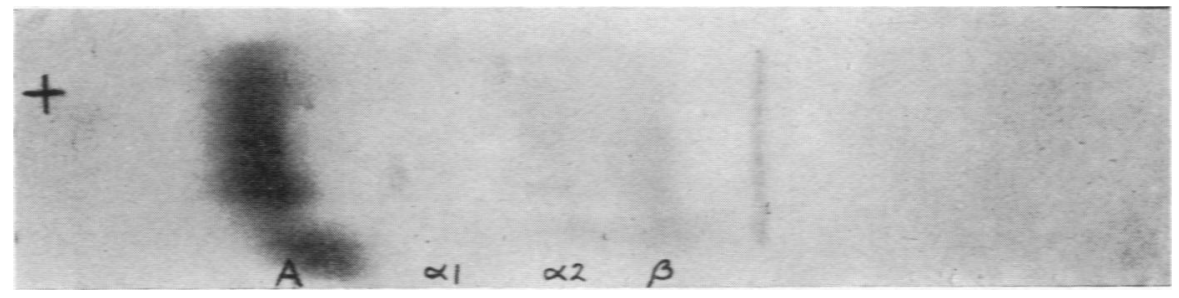

FiG. 4.-Electrophoresis of serum proteins on May 15, 1952

\section{Discussion}

Initial investigation in our case showed that the oedema was related to hypoproteinaemia. The boy was not premature, and there was no evidence of anaemia or of cardiac or renal disease. When the serum albumin fell below $2 \mathrm{~g}$. per $100 \mathrm{ml}$. the oedema tended to increase rapidly, and when the albumin level was raised by plasma transfusion a marked diuresis occurred. The hypoproteinaemia was not due to a lack of protein in the diet or to an absorption defect, as symptoms were present from birth. Albuminuria was consistently absent. It appeared, therefore, that synthesis of the serum proteins was impaired.

On two occasions when amino-aciduria was marked, the serum amino nitrogen level was much higher than at other times, This suggested that the increased amino-aciduria reflected the raised serum level of amino-acids as in Dent's group of hepatic cystinuria. It has already been shown how the combination of hypoproteinaemic oedema and amino-aciduria might be expected to result from liver disease and so far the facts in our case appeared to fit in with this concept. Thompson, McQuarrie and Bell (1936) described a child in whom hypoproteinaemia was thought to result from an atrophy of hepatic cells and this was demonstrated at necropsy.

In our case no confirmatory evidence of hepatic disease was found: icterus and hepatomegaly were never present, other liver function tests were normal deficiency of the total serum proteins for which no cause was found. At necropsy the liver was macroscopically normal and the fatty infiltration probably resulted from the widespread staphylococcal infection. It seems likely that the symptoms of the two siblings were due to the same cause, and we suggest that they suffered from an inherent abnormality of amino-acid metabolism, manifested chiefly by an idiopathic hypoproteinaemia. The occurrence of intermittent amino-aciduria does not appear to have been noted previously in this condition.

Himsworth and Lindan (1949) discussed experimental work which showed that supplements of $x$-tocopherol reduced the liability of rats to develop massive hepatic necrosis due to cystine deficiency. We felt that the possibility that tocopherol was concerned in amino-acid metabolism warranted its trial in our case. During the first course of treatment a marked decrease in the amino-aciduria occurred. But the original increase in amino-aciduria was synchronous with infection, and this was being controlled with antibiotics during treatment with tocopherol. Therefore the improvement could have been due to control of infection alone. When tocopherol was withdrawn the amino-aciduria again increased, although at this time there was no evidence of any active infection. A second course of tocopherol was associated with a rapid improvement. Subsequently, amino-aciduria was normal or slightly in excess, but it increased temporarily on two occasions with intercurrent infections while tocopherol was still being 
administered. When tocopherol was finally withdrawn no increase in amino-aciduria resulted. Thus, there was little evidence of any beneficial effect from tocopherol. The most that could be said was that the effect of the initial withdrawal, and the early effect of the second course, suggested that improvement in amino-aciduria was hastened by the vitamin at that time.

The relationship of increased amino-aciduria to infections was presumably due to the accompanying increase in protein catabolism which would enhance the effects of any already existing abnormality. The serum proteins were abnormal throughout. Although their total value was occasionally normal, the albumin was always low, only rarely exceeding a value of $2.5 \mathrm{~g}$. per $100 \mathrm{ml}$., below which oedema tends to occur, and $\gamma$ globulin was virtually absent.

Schick and Greenbaum (1945) expressed surprise that their case of congenital hypoproteinaemia showed no susceptibility to infections in view of the absence of $\gamma$ globulin, which is accepted to be the main carrier of humoral antibodies. However a negative Schick test demonstrated the presence of a certain amount of these antibodies. Our case also had a negative Schick test, but it is of interest that both siblings developed widespread staphylococcal infections. Inability to form $\gamma$ globulin appears to increase susceptibility to a certain type of infection at least.

\section{Summary}

An infant who had hypoproteinaemic oedema from birth is described. The serum albumin concentration was persistently low, and $\gamma$ globulin virtually absent. The presence of intermittent aminoaciduria is emphasized.

There was a history of a sibling with hypoproteinaemic oedema for which no cause was found.

It is postulated that both infants suffered from an inherent abnormality of amino-acid metabolism manifested chiefly as idiopathic hypoproteinaemia.

Both developed widespread staphylococcal infections.

$x$-Tocopherol had very little, if any, effect on the progress of the present case.

We wish to thank Dr. H. V. L. Finlay for permission to publish this case and for much helpful advice. Dr. C. E. Dent for confirming our chromatograph findings and his valuable criticism, and Mr. Denis J. Browne and Dr. Martin Bodian for permission to publish details of the first sibling.

REFERENCES

Albanese, A A and Irby, V (1945). J Lab clin Med, 30, 718.

Cohn, C. and Wolfson, W. Q. (1948). Ibid., 33, 367

Debré, R. (1947). Le Syndrome de Diabéte Rénal, p. 30 . Paris.

Dent, C. E. (1950). Personal Communication.

- (1951). Expos. ann. Biochim. med., 13. 79

Hertzog, F. V. and Faust, O. A. (1950). J. Pediat., 36, 641.

Himsworth, H. P. and Lindan, O. (1949). Nature, Lond., 163, 30.

Holzel, A., Komrower, G. M. and Wikon, V. K. (1952). Brit. med. J., $1,194$.

Homburger, F. and Petermann, M. L. (1949). Blood, 4, 1085.

Martin, N. H., Morris, R. and Smith, M. (1950). J. clin. Path., 3, 266.

Mellinkoff, S., Roth, B. and MacLaggan, J. (1945). J. Pediat., 27, 338.

Schick, B. and Greenbaum, J. W. (1945). Ibid., 27, 241.

Thompson, W. H., McQuarrie, I. and Bell, E. T. (1936). Ibid., 9, 604. 